\title{
Działalność przemysłowa w warunkach wzrastającej internacjonalizacji i globalizacji na przykładzie wybranych produktów
}

\author{
USTALENIA TERMINOLOGICZNE \\ I CHARAKTERYSTYKA PROCESU GLOBALIZACJI
}

Celem pracy jest przedstawienie przebiegu procesów globalizacji zachodzących na płaszczyźnie działalności przemysłowej w wybranych jej działach: hutnictwie i produkcji farmaceutyków.

Termin globalizacja, mimo że powszechnie stosowany, jest bardzo niejednoznaczny. W bogatej literaturze poświęconej tej problematyce można znaleźć bardzo wiele definicji i charakterystyk tego procesu. Brak jednoznacznej definicji wynika głównie z tego, że jest to proces wielowymiarowy, który można analizować z różnych punktów widzenia. Niektórzy badacze porównują go z procesami internacjonalizacji, przy czym albo utożsamiają obydwa pojęcia (por. Kukułka 2002), bądź traktują globalizację jako jedną z form internacjonalizacji (por. Liberska 2002). Z kolei według koncepcji P. Dickena (1998) te dwa procesy różnią się istotnie między sobą. Internacjonalizacja nie tylko jest terminem wcześniejszym od globalizacji, ale i odnosi się jedynie dla oznaczenia procesów intensyfikacji powiązań między państwami, natomiast globalizację - obok geograficznego rozszerzenia działalności - cechuje również wyraźna integracja funkcjonalna. Ponadto często w literaturze termin globalizacja stosowany jest zamiennie $\mathrm{z}$ innymi, jak międzynarodowa integracja gospodarcza czy transnacjonalizacja gospodarki. Charakterystykę tych różnych procesów wraz $\mathrm{z}$ ich odniesieniem do samej globalizacji systematyzuje tab. 1.

Globalizacja jako proces wielowymiarowy zachodzi na różnych płaszczyznach współczesnego życia politycznego, społecznego, ekonomicznego i kulturowego. Charakterystycznymi jej przejawami w aspekcie politycznym jest m.in. umacnianie się roli ponadnarodowych korporacji przemysłowych, handlowych i finansowych, co prowadzi do osłabienia roli państw narodowych. Globalne reguły działania dyplomacji, narzucane przez m.in. G-8, Światową Organizację Handlu (WTO), Międzynarodowy Fundusz Walutowy (IMF), Bank Światowy, konferencje ekonomiczne w Davos, ograniczają możliwości rządów do prowadzenia polityki takiej, jakiej chcą ich obywatele. Przejawami globalizacji na tej płaszczyźnie 
Tabela 1. Charakterystyka procesu globalizacji i jemu pokrewnych

\begin{tabular}{|c|c|c|}
\hline forma procesu & ogólna charakterystyka przejawów procesu & $\begin{array}{l}\text { odniesienie do globalizacji } \\
\text { (uwagi) }\end{array}$ \\
\hline internacjonalizacja & $\begin{array}{l}\text { rozwój stosunków międzynarodowych między } \\
\text { względnie niezależnymi gospodarkami oraz } \\
\text { przedsiębiorstwami narodowymi; także po- } \\
\text { szerzanie zasięgu geograficznego tych zjawisk }\end{array}$ & $\begin{array}{l}\text { w tradycyjnym rozumieniu - } \\
\text { w pewnej opozycji do globali- } \\
\text { zacji - jako niższa jakościowo } \\
\text { forma tego procesu }\end{array}$ \\
\hline globalizacja & $\begin{array}{l}\text { poszerzenie i pogłębienie się współzależności } \\
\text { między krajami (i regionami) wskutek rosnących } \\
\text { przepływów międzynarodowych oraz działalno- } \\
\text { ści korporacji transnarodowych, co prowadzi do } \\
\text { jakościowo nowych powiązań między przedsię- } \\
\text { biorstwami, rynkami i gospodarkami }\end{array}$ & \\
\hline $\begin{array}{l}\text { międzynarodowa } \\
\text { integracja gospo- } \\
\text { darcza }\end{array}$ & $\begin{array}{l}\text { scalanie się rynków, powstanie i rozwój glo- } \\
\text { balnej sieci powiązań produkcyjnych, techno- } \\
\text { logicznych i finansowych, również w postaci } \\
\text { ugrupowań gospodarczych regionalnych } \\
\text { i instytucji globalnych }\end{array}$ & $\begin{array}{l}\text { poszerzenie i pogłębienie tego } \\
\text { procesu uznaje się za przejaw } \\
\text { globalizacji; (jednakże regional- } \\
\text { ne organizacje integracyjne czę- } \\
\text { sto uznaje się za barierę dla nie- } \\
\text { których procesów globalizacji) }\end{array}$ \\
\hline transnacjonalizacja & $\begin{array}{l}\text { wzrost stopnia powiązań gospodarki z gospo- } \\
\text { darką światową poprzez działania korporacji } \\
\text { transnarodowych (drogą transferu kapitału, } \\
\text { technologii, wyspecjalizowanego personelu } \\
\text { itp.) - penetracja gospodarek narodowych } \\
\text { przez korporacje transnarodowe }\end{array}$ & $\begin{array}{l}\text { może - choć nie zawsze - być } \\
\text { składową procesów globali- } \\
\text { zacji (warunek: powstawanie } \\
\text { nowych jakościowo współ- } \\
\text { zależności) }\end{array}$ \\
\hline
\end{tabular}

Źródło: opracowanie własne w oparciu o B. Liberska 2002

są również realne zagrożenia stabilności politycznej, wynikające z rozwoju korupcji międzynarodowej oraz ugrupowań mafijnych. Na płaszczyźnie ekonomicznej globalizacja oznacza postępujące procesy integrowania się rynków krajowych w jeden globalny rynek towarów, usług i kapitału, które stają się coraz bardziej powiązane i współzależne. W wyniku upodabniania się norm i standardów wytwarzania oraz przestrzennej reorganizacji produkcji pojawiają się produkty globalne, tj. odpowiadające każdemu konsumentowi na świecie. Spektakularnym przejawem globalizacji jest szybka dyfuzja informacji i innowacji, przede wszystkim w dziedzinie technologii, czy też poszukiwanie nowych koncepcji, jak np. koncepcja gospodarki cyfrowej, koncepcja gospodarki opartej na wiedzy. Na płaszczyźnie kulturowej można zaobserwować globalne zderzenia cywilizacji i próby integracji kultur, m.in. w międzynarodowych programach ochrony dóbr kultury, promocji języków, literatury, sztuki i nauki, jak również w intensyfikacji zjawisk kultury masowej i upodabniania się stylów konsumpcji na całym świecie.

Wydaje się, że dobrym ujęciem syntetyzującym współczesne procesy globalizacji byłoby, zamiast formułowania kolejnych definicji, zebranie i przedstawienie najważniejszych cech charakteryzujących te procesy, zarazem najczęściej powtarzających się w opracowaniach z tego zakresu. Do takich można zaliczyć:

- kompresję czasu i przestrzeni (np. przekaz satelitarny informacji ma charakter ponadgraniczny i natychmiastowy)

- erozję granic i zniesienie barier geograficznych w przepływach towarów, technologii, kapitałów, ludzi itd. 
- rozciaganie działalności ekonomicznej ponad granice

- intensyfikację powiązań międzynarodowych

- pogłębienie współzależności

- penetrację gospodarek narodowych przez korporacje transnarodowe

- wzrost skali, mobilności i integracji światowych rynków finansowych (inwestycje)

- uniformizację

- niesymetryczność zależności i powiązań - daje efekt marginalizacji grupy państw peryferyjnych, pozostających poza zasięgiem zysków

- globalizacja uruchamia procesy przeciwstawne prowadzące do dowartościowania elementów lokalnych, a nawet rozwoju nacjonalizmów.

$\mathrm{Na}$ uwagę zasługuje również wymiar geograficzny globalizacji, polegający przede wszystkim na zmianie znaczenia granic państwowych przy wzrastającym znaczeniu intensywności połączeń i współzależności między państwami. Współczesny system polityczno-terytorialny świata ujmuje się bowiem m.in. jako układ powiązań transgranicznych i supragranicznych - powiązań globalnych.

\section{KORPORACJE TRANSNARODOWE \\ JAKO GŁÓWNI UCZESTNICY PROCESÓW GLOBALIZACJI}

Analizując współczesne procesy globalizacji należy zwrócić uwagę, że główną przesłanką ich rozwoju stały się rewolucyjne zmiany technologiczne w dziedzinie informatyki i telekomunikacji, przede wszystkim upowszechnienie się komputerów i zwielokrotnienie ich zdolności operacyjnych, a następnie rozwój łączności internetowej. Miernikiem tych rewolucyjnych zmian może być wzrost szybkości przekazu informacji: jeśli w latach 80 . możliwe było przekazywanie 1 stronicy tekstu na sekundę, to w 2000 r. przekazywano już 90 tys. stronic na sekundę (Kukułka 2002, s. 19). Drugą ważną przesłanką rozwoju procesów globalizacyjnych jest deregulacja gospodarek narodowych, ich otwarcie na zagraniczną konkurencję oraz liberalizacja handlu i przepływów kapitałów.

Główną rolę w procesach globalizacji gospodarki światowej odgrywają korporacje transnarodowe. Ich działalność prowadzi do integracji rynków towarowych i usług, powstawania globalnych sieci produkcji, wzrostu powiązań między przedsiębiorstwami w różnych krajach, a poprzez decyzje lokalizacji produkcji przyczyniają się do restrukturyzacji gospodarek narodowych.

Określenia „korporacje transnarodowe” dla oznaczenia niepaństwowych uczestników stosunków międzynarodowych po raz pierwszy użyto w 1974 r. na Sesji Ekonomicznej i Społecznej Narodów Zjednoczonych (Moraczewska 2002, s. 88). Według danych UNIDO liczba korporacji transnarodowych zwiększyła się w szybkim tempie, z około 40 tys. w 1994 r. do 63 tys. w 1999 r., a liczba ich filii zwiększyła się w tym okresie z 270 tys. do 690 tys. (wg Zorska 1998, s. 48; Liberska 2002, s. 39). Korporacje transnarodowe są więc podstawowymi uczestnikami procesów globalizacji. Można nawet stwierdzić, że korporacje odbierają państwom w dużej części władzę nad rynkiem: na publikowanej przez tygodnik „Wprost” liście rankingowej stu najpotężniejszych uczestników stosunków międzynarodowych (wg kryterium wielkości PKB i wielkości przychodu) państw jest mniej niż korpora- 
cji. A zatem teza o słabnącej roli państw w konfrontacji z korporacjami i stale rosnącej pozycji wielkich koncernów wydaje się uzasadniona.

Bardzo duże znaczenie korporacji transnarodowych w gospodarce światowej oraz ich wiodąca rola $w$ procesach globalizowania działalności gospodarczej skłaniają wielu autorów do prób zdefiniowania tych podmiotów. Jedną z dobrze syntetyzujących definicji wydaje się być określenie P. Dickena (1992), który przyjmuje, iż (cyt. za Zorska 1998, s. 50) „korporacja transnarodowa jest organizacją, która koordynuje działalność produkcyjno-handlową z jednego ośrodka podejmującego strategiczne decyzje". Korporacje transnarodowe tworzą federacje odrębnych firm narodowych o różnych strukturach: w postaci filii lub oddziałów, a także joint venture czy holdingów. Struktury te połączone są w sieci powiązań między korporacją macierzystą a jej przedstawicielstwami zagranicznymi, tworząc również globalną sieć zatrudnienia. $\mathrm{W}$ ramach korporacji następuje rozproszenie funkcji przedsiębiorstwa w skali różnych krajów dla znalezienia najlepszych warunków produkcji i zbytu. Ich działalność przenika granice państw, są międzynarodowymi kanałami przepływu dóbr, usług, technologii, ludzi i kapitału, a przez bezpośrednie inwestycje zagraniczne oddziałują na wszystkie sfery życia: gospodarkę, społeczeństwo i kulturę, na politykę państw i stosunki międzynarodowe. Zmieniają one strukturę geograficzną świata, podejmując przedsięwzięcia z pominięciem barier czasu i granic. Dążąc do zdominowania światowego handlu i produkcji powodują wzrost znaczenia konkurencyjności. Korporacje oddziałują na międzynarodową specjalizację produkcji poszczególnych państw i międzynarodowy podział pracy. Z funkcjonowaniem korporacji transnarodowych związane są jednak także negatywne zjawiska społeczno-gospodarcze, takie jak np. wzrost bezrobocia następujący w wyniku konsolidacji rynków w drodze fuzji i przejęć. Trudno również nie zauważyć niebezpieczeństwa konfliktów globalnych, powstających przy udziale korporacji, takich jak np. wojny handlowe $w$ imię interesów narodowych lub korporacyjnych czy niekontrolowany przepływ pieniędzy wywołujących z kolei konflikty lokalne, a nawet rozwój przestępczości (syndykaty mafijno-narkotykowe).

Ze względu na różne typy powiązań między poszczególnymi jednostkami składowymi w tab. 2. wyodrębniono cztery modele struktury korporacji (na podstawie Czupiał 1997; Moraczewska 2002; Zorska 1998).

Badania nad stopniem umiędzynarodowienia przedsiębiorstw prowadzi UNCTAD (Konferencja ONZ ds. Handlu i Rozwoju). W ramach tych badań sformułowany został wskaźnik transnacjonalizacji, który jest porównaniem zaangażowania korporacji w kraju i zagranica. Wskaźnik ten jest syntezą trzech wskaźników szczegółowych, charakteryzujących każdą z analizowanych korporacji: udziału aktywów zagranicznych, udziału sprzedaży za granicą w całości sprzedaży oraz udziału zatrudnienia w filiach zagranicznych. Do analiz brane są pod uwagę tylko przedsiębiorstwa produkcyjne, a nie finansowe, jak np. banki. Światowa setka największych korporacji transnarodowych w 2000 r. zatrudniała 6,4 mln pracowników poza granicami krajów macierzystych. Największą korporacją pod względem aktywów zagranicznych była korporacja telekomunikacyjna Vodafone Group oraz General Electric, produkująca sprzęt elektryczny i elektroniczny (por. tab. 3). Kolejne miejsca w pierwszej dziesiątce zajmowały korporacje paliwowe Exxon, Royal Dutch/Shell Group i BP. Na kolejnych miejscach znalazły się korporacje producentów samochodów: General Motors, Toyota, Fiat i VW. W pierwszej dziesiątce znalazła się też korporacja pochodzenia francuskiego Vivendi Universal o zdywersyfikowanej działalności. Blisko 90\% korporacji z listy 100 pochodziło z krajów triady: Stany Zjednoczone - Unia Europejska - Japonia. 
Tabela 2. Modele korporacji ze względu na powiązania między jednostkami składowymi

\begin{tabular}{|c|c|c|}
\hline $\begin{array}{c}\text { Kierunek wzrostu } \\
\text { stopnia umiędzynaro- } \\
\text { dowienia }\end{array}$ & $\begin{array}{c}\text { model } \\
\text { korporacji }\end{array}$ & Charakterystyka \\
\hline & międzynarodowa & $\begin{array}{l}\text { działa w więcej niż jednym kraju, duża sprzedaż na } \\
\text { rynkach zagranicznych, choć ciagle mniejsza niż na } \\
\text { krajowym, prowadzi produkcję zagraniczna, posiada } \\
\text { oddział zagraniczny funkcjonalnie podporządkowany } \\
\text { strukturze macierzystej }\end{array}$ \\
\hline & wielonarodowa & $\begin{array}{l}\text { działa w kilku krajach, eksport przekracza } 50 \% \text { sprze- } \\
\text { daży krajowej, znaczna liczba jednostek zagranicz- } \\
\text { nych, dla zarządzania którymi tworzy lokalne subcen- } \\
\text { tra (np. dla Europy, Ameryki Łacińskiej), koordynują- } \\
\text { ce działalność jednostek w tych regionach, ale cen- } \\
\text { trum zarządzające znajduje się w macierzystym kraju, } \\
\text { stamtąd pochodzi kadra, tam też skupione są jednostki } \\
\text { badawczo-rozwojowe, laboratoria centralne, czerpane } \\
\text { wzory kultury; stosowane są preferencje dla kraju } \\
\text { macierzystego }\end{array}$ \\
\hline & transnarodowe & $\begin{array}{l}\text { sposoby budowania i koordynacji działalności w wie- } \\
\text { lu krajach, prowadzonych w celu uzyskania globalnej } \\
\text { przewagi konkurencyjnej, przezwyciężenie narodo- } \\
\text { wych ograniczeń, działanie na podstawie kadry i kapi- } \\
\text { tału miejscowego, tj. kraju goszczącego, a więc pomi- } \\
\text { ja się kulturę, politykę kraju macierzystego - statuty } \\
\text { przedsiębiorstw regulują skład narodowościowy za- } \\
\text { rządów, eksport przewyższa sprzedaż krajową, pro- } \\
\text { dukcja zagraniczna dominuje, również wartość mająt- } \\
\text { ku za granicą przewyższa krajową }\end{array}$ \\
\hline & globalna & $\begin{array}{l}\text { a) kumulacja kapitału za granica przewyższa krajową, } \\
\text { b) działa na rynkach kapitałowych (notowania gieł- } \\
\text { dowe) kilku państw, c) globalna sieć zatrudnienia } \\
\text { i duży udział pracowników zagranicznych w stosunku } \\
\text { do krajowych, d) jest kilku najważniejszych udzia- } \\
\text { łowców zagranicznych decydujących i zarządzających } \\
\text { e) postrzeganie społeczne jako firmy niezwiązanej } \\
\text { z żadnym konkretnym państwem }\end{array}$ \\
\hline
\end{tabular}




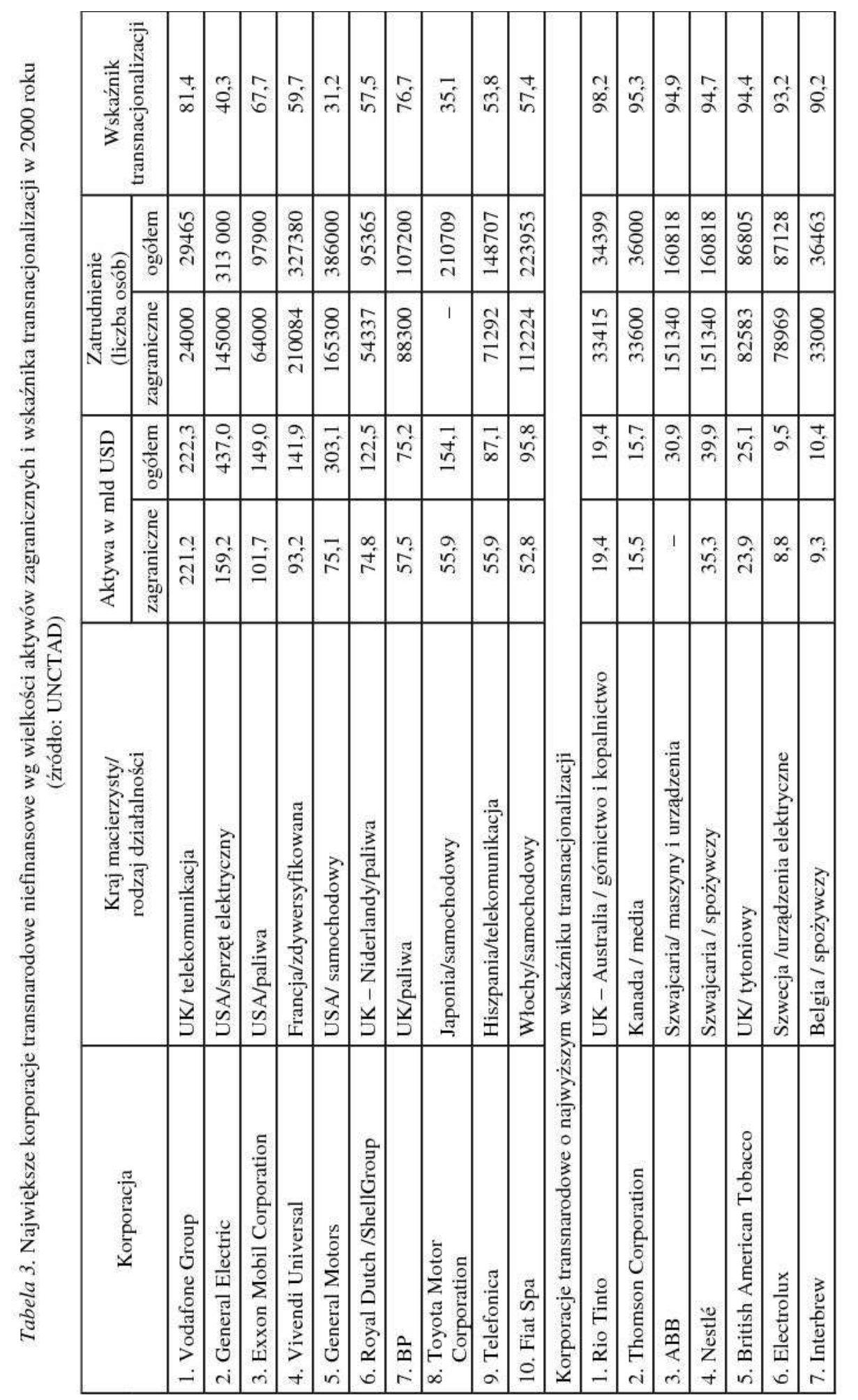


Najliczniej reprezentowane były branże: samochodowa, elektroniczna, paliwowa, chemiczna i farmaceutyczna, a pod względem liczby zatrudnionych największymi są korporacje telekomunikacyjne: Motorola, Ericsson i Siemens. Inaczej wygląda jednak zestawienie korporacji według wskaźnika transnacjonalizacji, którego pierwszych 7 pozycji zawiera również tabela 3. Do korporacji najbardziej transnarodowych w 2000 r. zaliczano brytyjsko-australijską korporację górniczą Rio Tinto oraz kanadyjską korporację Thomson. Bardzo wysokie wskaźniki transnacjonalizcji posiadały również korporacje działające w obszarze produkcji elektryczno-elektronicznej, takie jak ABB, Electrolux, Philips Electronics, a także zajmujące się produkcją artykułów spożywczych, takie jak Nestlé, Danone Group, Cadbury-Schweps, British American Tobacco oraz korporacje farmaceutyczne: Astrazeneca i AkzoNobel, Roche Group. W tym zestawieniu dominują firmy z państw będących względnie małymi rynkami macierzystymi: Kanada, Szwajcaria, Szwecja, Holandia.

Najbardziej spektakularnym efektem tworzenia i funkcjonowania tak potężnych organizacji gospodarczych jak korporacje transnarodowe jest efekt synergii, jaki powstaje między finansowaniem, zarządzaniem i produkcją realizowanymi w poszczególnych częściach składowych korporacji. W ostatnich latach można ponadto zaobserwować pewne stosunkowo nowe formy współpracy między korporacjami, polegające na strategicznych aliansach, fuzjach i przejęciach. Mają one na celu nie tylko redukcję kosztów i ryzyka niepowodzenia inwestycji na wypadek wystapienia kryzysu w jakiejkolwiek części świata, ale skierowane są przede wszystkim na racjonalizację działań w ramach globalnej sieci produkcji oraz zapewnienie określonej elastyczności, koniecznej do reagowania w turbulentnym środowisku współczesnego świata.

\section{PRODUKCJA STALI I FARMACEUTYKÓW W WARUNKACH WZRASTAJĄCEJ GLOBALIZACJI}

Celem tego rozdziału jest przedstawienie roli największych korporacji o funkcjach międzynarodowych, transnarodowych i globalnych, a także najbardziej spektakularnych fuzji i przejęć oraz aliansów i joint-ventures w produkcji stali i produkcji farmaceutyków, a także rolę handlu międzynarodowego w procesach globalizacji w tych działach produkcji przemysłowej.

\section{Produkcja stali w układzie globalnym i regionalnym}

Przez cały wiek XX stal stanowiła jeden z najważniejszych produktów światowej gospodarki. Według ilości wyprodukowanej stali szacowano potencjał gospodarczy i militarny krajów. W ostatniej dekadzie XX wieku produkowano na świecie przeciętnie ok. $750 \mathrm{mln}$ ton stali rocznie (por. ryc. 1). Na początku lat 90. nastąpił jednak dosyć wyraźny spadek produkcji stali, przekroczenie poziomu produkcji z $1990 \mathrm{r}$. miało miejsce dopiero w $1997 \mathrm{r}$. (ryc. 1), przyczyniło się to do sformułowania tezy o zmierzchu roli hutnictwa żelaza. Kolejna faza wzrostu produkcji nastąpiła w latach 2000-2002, pomimo ograniczenia zdolności 
produkcyjnych w wielu krajach wysoko rozwiniętych. W ciągu ostatnich kilkunastu lat wyraźnej zmianie uległa geograficzna struktura produkcji. Jeszcze w 1990 r. liczyły się trzy kraje: ZSRR, Japonia i Stany Zjednoczone Ameryki, które razem wytwarzały prawie połowę światowej produkcji stali surowej (tj. 353,7 mln t, czyli 45,9\% produkcji światowej). W 1995 r. udział Japonii, Stanów Zjednoczonych oraz państw powstałych po rozpadzie ZSRR w światowej produkcji stali spadł do 36,7\% (275,9 mln t). Szczególny spadek produkcji stali w latach 1990-1995 nastąpił w krajach byłego ZSRR (z 154,0 mln t do 79,1 mln t) oraz w postkomunistycznych krajach Europy Środkowo-Wschodniej (z 47,0 mln t do 34,8 mln t) - por. tab. 4.

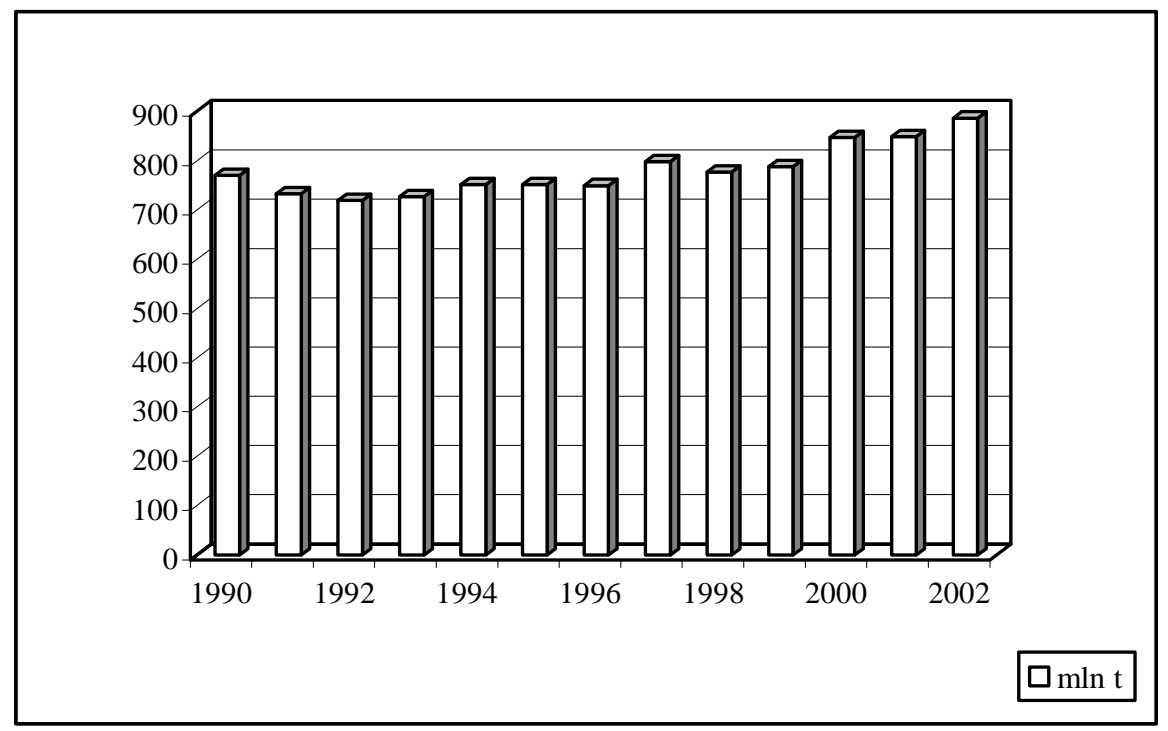

Ryc. 1. Produkcja stali surowej na świecie w latach 1990-2002

Źródło: Steel Statistical Yearbook 2002, Brussels

Tabela 4. Produkcja stali w krajach byłego ZSRR i w krajach postkomunistycznych w Europie Środkowo-Wschodniej w latach 1991-2001 (mln ton)

\begin{tabular}{|l|r|r|r|r|r|r|}
\cline { 2 - 7 } \multicolumn{1}{c|}{} & $\mathbf{1 9 9 1}$ & $\mathbf{1 9 9 3}$ & $\mathbf{1 9 9 5}$ & $\mathbf{1 9 9 7}$ & $\mathbf{1 9 9 9}$ & $\mathbf{2 0 0 1}$ \\
\hline \hline Kraje b. ZSRR & 132,8 & 98,1 & 79,1 & 81,0 & 86,1 & 100,1 \\
\hline Polska & 10,4 & 9,9 & 11,9 & 11,6 & 8,8 & 8,8 \\
\hline Rep. Czeska & \multirow{2}{*}{12,1} & 6,8 & 7,2 & 6,8 & 5,6 & 6,3 \\
\cline { 1 - 7 } Słowacja & & 3,9 & 4,0 & 3,8 & 3,6 & 4,0 \\
\hline Węgry & 1,9 & 1,8 & 1,9 & 1,7 & 1,8 & 2,0 \\
\hline Rumunia & 7,1 & 9,9 & 11,9 & 11,6 & 8,8 & 8,8 \\
\hline Bułgaria & 1,6 & 1,9 & 2,7 & 2,6 & 1,9 & 2,0 \\
\hline b. Jugosławia & 2,2 & 0,7 & 0,7 & 1,6 & 0,8 & 1,2 \\
\hline
\end{tabular}

Źródło: Steel Statistical Yearbook, 2002

Produkcja stali w wysoko rozwiniętych krajach tworzących G-7 w latach 1991-2001 utrzymywała się na zbliżonym poziomie i w 1990 r. wyniosła 318,3 mln ton, w 1995 r. $316,8 \mathrm{mln} \mathrm{t}$, a w $2001 \mathrm{r}$. - 312,6 mln t, jednakże ich udział w produkcji światowej spadł z 41,3\% w 1990 r. do 36,8\% w 2001 r. (por. tab. 5). 
Tabela 5. Produkcja stali w G-7 (mln ton)

\begin{tabular}{|l|r|r|r|r|r|r|}
\cline { 2 - 7 } \multicolumn{1}{c|}{} & $\mathbf{1 9 9 1}$ & $\mathbf{1 9 9 3}$ & $\mathbf{1 9 9 5}$ & $\mathbf{1 9 9 7}$ & $\mathbf{1 9 9 9}$ & $\mathbf{2 0 0 1}$ \\
\hline \hline Japonia & 109,6 & 99,6 & 101,6 & 104,5 & 94,2 & 102,9 \\
\hline $\begin{array}{l}\text { Stany Zjedno- } \\
\text { czone }\end{array}$ & 79,7 & 88,8 & 95,2 & 98,5 & 97,4 & 90,1 \\
\hline Niemcy & 42,2 & 37,6 & 42,1 & 45,0 & 42,1 & 44,8 \\
\hline Włochy & 25,1 & 25,7 & 27,8 & 25,8 & 24,9 & 26,7 \\
\hline Francja & 18,4 & 17,1 & 18,1 & 19,8 & 20,2 & 19,3 \\
\hline Wlk. Brytania & 16,5 & 16,6 & 17,6 & 18,5 & 16,3 & 13,5 \\
\hline Kanada & 13,0 & 14,4 & 14,4 & 15,6 & 16,2 & 15,3 \\
\hline G-7 (razem) & 304,5 & 299,8 & 316,8 & 327,7 & 311,3 & 312,6 \\
\hline
\end{tabular}

Źródło: Steel Statistical Yearbook, 2002

Zdecydowanie wzrosła rola 4 krajów azjatyckich w światowej produkcji stali: Chińskiej Republiki Ludowej, Republiki Korei, Indii i Tajwanu, które w 1991 r. produkowały łącznie 125,1 mln t stali (tj. 17,0\% produkcji światowej), a w 2001 roku - 240,7 mln t (28,3\% produkcji światowej) - zmiany te przedstawia tab. 6 .

Tabela 6. Produkcja stali w „,czwórce azjatyckiej” (mln ton)

\begin{tabular}{|l|c|c|c|r|r|r|}
\cline { 2 - 7 } \multicolumn{1}{c|}{} & $\mathbf{1 9 9 1}$ & $\mathbf{1 9 9 3}$ & $\mathbf{1 9 9 5}$ & $\mathbf{1 9 9 7}$ & $\mathbf{1 9 9 9}$ & $\mathbf{2 0 0 1}$ \\
\hline \hline ChRL & 71,0 & 89,5 & 95,4 & 108,9 & 124,0 & 152,3 \\
\hline Rep. Korei & 26,0 & 33,0 & 36,8 & 42,6 & 41,0 & 43,9 \\
\hline Indie & 17,1 & 18,2 & 22,0 & 24,4 & 24,3 & 27,3 \\
\hline Tajwan & 11,0 & 12,0 & 11,6 & 16,0 & 15,4 & 17,2 \\
\hline Razem & 125,1 & 152,7 & 165,8 & 191,9 & 204,7 & 240,7 \\
\hline
\end{tabular}

Źródło: Steel Statistical Yearbook, 2004

Światowa produkcja stali w 2002 roku wyniosła 886,8 mln t i wzrosła w latach 1990-2001 o 15,1\%. Największym producentem stali w 1990 roku był ZSRR, w latach 1991-1995 - Japonia, a od 1996 roku ChRL. Udział ChRL w produkcji światowej wynosił w 1996 roku 13,5\%, ale w 2002 roku wzrósł do poziomu 21,4\%. Należy też zwrócić uwagę, że skład czołowych 10 producentów stali na świecie nie uległ zmianie w latach 1992-2001, natomiast awansowały na wyższe pozycje ChRL, Republika Korei i Indie (por. tab. 7). Czołowa dziesiątka producentów stali wytwarzała w ostatnim okresie ok. $70 \%$ produkcji światowej.

Tabela 7. Najwięksi producenci stali na świecie 1990-2002 (produkcja w mln t)

\begin{tabular}{|r|lr|lr|lr|}
\hline Lp. & \multicolumn{2}{|c|}{ 1990 r. } & \multicolumn{2}{c|}{ 2000 } & \multicolumn{2}{c|}{ 2002 } \\
\hline \hline 1 & ZSRR & 154,0 & Chińska RL & 127,2 & Chińska RL & 181,6 \\
\hline 2 & Japonia & 110,0 & Japonia & 106,4 & Japonia & 107,7 \\
\hline 3 & St. Zjednoczone & 89,7 & St. Zjednoczone & 101,8 & St. Zjednoczone & 92,2 \\
\hline 4 & Chińska RL & 66,3 & Rosja & 59,1 & Rosja & 59,8 \\
\hline 5 & Niemcy & 44,0 & Niemcy & 46,4 & Rep. Korei & 45,4 \\
\hline 6 & Włochy & 25,5 & Rep. Korei & 43,1 & Niemcy & 45,0 \\
\hline 7 & Rep. Korei & 23,1 & Ukraina & 31,4 & Ukraina & 33,4 \\
\hline 8 & Brazylia & 20,6 & Brazylia & 27,9 & Brazylia & 29,6 \\
\hline 9 & Francja & 19,0 & Indie & 26,9 & Indie & 28,8 \\
\hline 10 & Wlk. Brytania & 17,8 & Włochy & 26,7 & Włochy & 26,1 \\
\hline 11 & Indie & 15,0 & Francja & 21,0 & Francja & 20,3 \\
\hline 12 & Polska & 13,6 & Tajwan & 17,0 & Tajwan & 18,2 \\
\hline
\end{tabular}

Źródło: Steel Statistical Yearbook, 2004 
W produkcji stali na świecie dominują producenci zrzeszeni w wielkie korporacje, najczęściej w formie spółek. Dziesięć największych spółek stalowych wytwarzało w 2002 roku ponad 1/4 światowej produkcji stali surowej (por. tab. 8). Największą spółką stalową w 2002 roku był Arcelor, produkujący ok. $44 \mathrm{mln}$ t stali. Spółka ta powstała w lutym 2001 roku poprzez zamianę akcji trzech firm: francuskiej Usinor (56,5\% ogółu udziałów), luksemburskiej Arbed $(23,4 \%)$ i hiszpańskiej Arcelia $(20,1 \%)$. Nowa spółka (początkowo miała się nazywać NewCo) zatrudniała ok. 110 tys. pracowników.

Tabela 8. Największe koncerny stalowe współczesnego świata i ich produkcja (w mln t)

\begin{tabular}{|c|c|c|c|c|c|c|c|c|}
\hline Lp. & \multicolumn{2}{|l|}{1973} & \multicolumn{2}{|l|}{1996} & \multicolumn{2}{|l|}{2000} & \multicolumn{2}{|l|}{2002} \\
\hline 1 & Nippon Steel & 41,0 & Nippon Steel & 26,3 & Nippon Steel & 28,4 & Arcelor & 44,0 \\
\hline 2 & US Steel & 31,7 & POSCO & 24,2 & POSCO & 27,7 & LNM Group & 34,8 \\
\hline 3 & British Steel & 23,9 & British Steel & 15,7 & Arbed & 24,0 & Nippon Steel & 29,8 \\
\hline 4 & Bethlehem Steel & 21,5 & Usinor-Sacilor & 15,5 & Ispat International & 22,4 & NKK+Kawasaki & 28,9 \\
\hline 5 & Nippon Kokan & 16,0 & Riva & 14,4 & Usinor & 21,0 & POSCO & 28,1 \\
\hline 6 & Sumitomo MI & 14,5 & Arbed & 11,5 & Corus & 20,0 & Shanghai Baosteel & 19,5 \\
\hline 7 & Kawasaki Steel & 14,4 & SAIL & 11,4 & Thyssen Krupp & 17,7 & Corus & 16,8 \\
\hline 8 & Thyssen-Hütte & 14,2 & NKK & 11,1 & Shanghai Baosteel & 17,7 & Thyssen Krupp & 16,4 \\
\hline 9 & Finsider & 11,6 & US Steel & 10,7 & NKK & 16,0 & Riva & 15,0 \\
\hline 10 & Estel NW & 11,6 & Thyssen & 10,4 & Riva & 15,6 & US Steel & 14,4 \\
\hline & & & & & \multicolumn{2}{|c|}{ Produkcja razem: } & & 247,7 \\
\hline & & & & & \multicolumn{2}{|c|}{ \% produkcji światowej } & & 27,9 \\
\hline
\end{tabular}

Źródło: Kowalski 1978; Steel Statistical Yearbook 2002, IISI

Aby ułatwić sobie wchodzenie na coraz to nowe rynki, firmy dokonują dalszych fuzji i przejęć. W 1992 r. w Niemczech Krupp AG przejął innego producenta stali Hoesch AG, a w 1999 r. nastąpiła fuzja firmy stalowej z firmą Thyssen. W 1999 r. nastąpiło połączenie dwóch ważnych producentów stali w Europie: brytyjskiego British Steel z niderlandzkim Hoogovens, które utworzyły spółkę Corus. W 2002 r. nastapiła fuzja dwóch japońskich producentów stali: NKK i Kawasaki Steel. Nieco wcześniej, w 1998 r. powstała chińska grupa Shanghai Baosteel w wyniku przejęcia przez Baoshan Iron\&Steel holdingu Shanghai Metallurgical i Meishan Company. Również w Stanach Zjednoczonych doszło do istotnych zmian własnościowych wśród czołowych producentów stali: US Steel przejął zbankrutowaną National Steel z Mishawak, a International Steel w podobnych okolicznościach przejął giganta stalowego lat 70. Bethlehem Steel.

Kolejną formą penetracji rynków krajowych przez wielkie spółki stalowe jest ich udział w prywatyzacji kombinatów hutniczych w Europie Środkowo-Wschodniej, jak i w inwestycjach typu greenfield w tzw. gospodarkach wschodzących, a zwłaszcza w ChRL. Przykładem działań pierwszego typu może być kupno przez US Steel słowackiego kombinatu VSZ Koszyce i serbskiego kombinatu Sarbid Smederevo w 2003 r. oraz zabiegania o udział w prywatyzacji Polskich Hut Stali. Również Polskie Huty Stali zostały zakupione w ostateczności po długich negocjacjach przez koncern LNM (zarejestrowany formalnie na Arubie), który ponadto od 2002 r. jest właścicielem czeskiego kombinatu Novy Hut Kuncice. Budowę nowych walcowni i zakładów produkujących blachy samochodowe w Chinach w postaci spółek joint-ventures podjęły m.in. spółki Nippon Steel i Thysseen Krupp.

Ważnym przejawem globalizacji $\mathrm{w}$ dziedzinie produkcji stali i jej przetwórstwie jest tworzenie aliansów technologicznych, zwłaszcza w warunkach nadprodukcji stali na rynku 
światowym i konieczności obniżania kosztów. I tak japońskie spółki NKK, Sumitomo HI i Hitachi Zosen zawarły alians technologiczny w sferze produkcji stali budowlanej, a fińska Outokumpu i brytyjsko-szwedzka Avesta Sheffield w dziedzinie wytwarzania stali nierdzewnej. Dwa sojusze w dziedzinie prac badawczo-rozwojowych zawarła w 2002 r. japońska spółka Kobe Steel z Lucchini oraz Nippon Steel. Z kolei dwie spółki japońskie Nippon Steel i Kobe Steel w 2001 roku utworzyły wspólną sieć dystrybucji i zakupu surowców.

\section{Tendencje globalizacyjne w przemyśle farmaceutycznym}

Produkcja farmaceutyków na świecie zdominowana została przez wielkie wielonarodowe korporacje, działające globalnie, poprzez rozwój sieci współzależnych spółek i firm. Do największych korporacji należy amerykański Pfizer - firma o długoletniej tradycji (powstała w 1849 r.) i ugruntowanej marce. W 2001 r. jej dochody wyniosły 32 mld USD i zatrudniała ponad 90 tys. osób. W 2003 r. po fuzji z koncernem Pharmacia (który z kolei powstał w 1995 r. w wyniku połączenia szwedzkiej firmy farmaceutycznej Pharmacia AB z amerykańską firmą Upjohn), łączne obroty nowej grupy szacowano na 47,9 mld USD, a ich udział w światowym rynku leków szacowany jest na ok. 7\%. Drugą z kolei potężną korporacją farmaceutyczną pod względem wielkości sprzedaży w 2003 r. była GlaxoSmith Kline. Korporacja ta powstała w wyniku połączenia w 2001 r. brytyjskiego GlaxoWellcome (koncern ten ma również ok. 11\% udział w polskim rynku leków, dzięki m.in. zakupowi w 1998 r. poznańskiej Polfy) i amerykańskiego SmithKline Beecham, znanego z produkcji past do zębów, takich jak Aquafresh i Sensodyne. Po tej fuzji GSK posiada niewiele mniejszy od Pfizera, bo prawie 6,9\% udział w światowym rynku leków. Na trzecim miejscu pod względem wielkości sprzedaży w sierpniu i wrześniu 2003 r. znajdował się amerykański koncern Merck\&Co, którego obroty w I kwartale 2003 r. wynosiły 13,4 mld USD. Koncern ten specjalizuje się w sprzedaży preparatów na nadciśnienie i osteoporozę, a jego udział w światowym rynku leków szacowany jest na 5\%. Zestawienie 10 największych korporacji farmaceutycznych na świecie w 2001 i 2003 r. zawiera tab. 9.

Tabela 9. Największe korporacje farmaceutyczne w 2001 roku wg wielkości sprzedaży

\begin{tabular}{|c|l|l|c|c|l|}
\hline \multicolumn{5}{|c|}{$\mathbf{2 0 0 1}$} & \multicolumn{1}{c|}{$\mathbf{2 0 0 3}$} \\
\hline Lp. & \multicolumn{1}{|c|}{ Nazwa firmy } & Kraj & $\begin{array}{c}\text { Obroty } \\
{[\mathbf{w} \text { mld \$] }}\end{array}$ & $\begin{array}{c}\text { Wynik netto } \\
{[\mathbf{w} \text { mld \$] }}\end{array}$ & $\begin{array}{c}\text { Wg sprzedaży } \\
\text { w sierpniu i wrześniu }\end{array}$ \\
\hline 1 & Merck & USA & 47,7 & 7,3 & Pfizer \\
\hline 2 & Johnson\&Johnson & USA & 33,0 & 5,7 & GlaxoSmithKline \\
\hline 3 & Pfizer & USA & 32,3 & 7,8 & Merck\&Co \\
\hline 4 & GlaxoSmithKline & Wlk.Bryt & 29,5 & 4,5 & AstraZeneca \\
\hline 5 & Bristol-Myers Squibb & USA & 21,7 & 5,2 & Novartis \\
\hline 6 & Aventis & Francja & 20,5 & 1,3 & Johnson\&Johnson \\
\hline 7 & Pharmacia & USA & 19,3 & 1,5 & Bristol-Myers Squibb \\
\hline 8 & Novartis & Szwajcaria & 19,0 & 4,2 & Aventis \\
\hline 9 & Roche & Szwajcaria & 17,3 & 3,0 & Wyeth \\
\hline 10 & Astrazeneca & Wlk.Bryt. & 16,5 & 3,0 & Abbott \\
\hline
\end{tabular}

Źródło: Bilan du Monde, 2002; IMS Health 
Sprzedaż farmaceutyków na świecie stale wzrasta: w 1995 r. wartość sprzedanych leków oszacowano na 139,15 mld USD, w 1996 r. - 143,8 mld USD, a w pierwszych trzech kwartałach 2002 r. - 272,0 mld USD. Do ośmiu największych producentów leków należy niemalże $40 \%$ światowego rynku sprzedaży. Natomiast najbardziej chłonnym rynkiem są Stany Zjednoczone, gdzie w okresie od sierpnia 2002 r. do sierpnia 2003 r. wartość sprzedaży wyniosła 156,5 mld USD. Na drugim miejscu pod tym względem znajduje się Japonia - tam sprzedano w tym samym okresie farmaceutyków za 49,78 mld USD, na trzecim miejscu są Niemcy, którzy w tymże okresie zakupili leków za 20,5 mld USD (por. tab. 10).

Tabela. 10. Sprzedaż detaliczna leków w okresie 08.2002-08.2003

\begin{tabular}{|c|l|c|}
\hline Lp. & \multicolumn{1}{|c|}{ Kraj } & Wartość w mld \$ \\
\hline 1. & Stany Zjednoczone & 156,5 \\
\hline 2. & Japonia & 49,8 \\
\hline 3. & Niemcy & 20,5 \\
\hline 4. & Francja & 17,1 \\
\hline 5. & Wielka Brytania & 12,1 \\
\hline 6. & Włoch & 11,9 \\
\hline 7. & Kanada & 8,1 \\
\hline 8. & Hiszpania & 8,0 \\
\hline 9. & Meksyk & 6,1 \\
\hline
\end{tabular}

* łącznie z lekami szpitalnymi Źródło: IMS Health

Walka o rynki leków toczy się między gigantami farmaceutycznymi z wykorzystaniem coraz to nowych strategii. Jedną z nich są właśnie fuzje i przejęcia, które pozwalają na penetrację coraz to nowych obszarów świata farmaceutyków. I tak np. zanim doszło do fuzji Pfizera i Pharmacii, firmy te musiały uzyskać zgody urzędu antymonopolowego USA jak i Komisji Europejskiej ze względu na monopolistyczny charakter niektórych swoich produktów. Tak więc Pharmacia została zmuszona do sprzedaży konkurencji m.in. leku o podobnym działaniu jak viagra, w której produkcji była monopolistą, a Pfizer musiał udostępnić konkurencji formułę produkcji specyfiku urologicznego darifenacin.

Innym przykładem fuzji dla zdobycia nowych rynków jest utworzenie koncernu Aventis w 1999 r. z połączenia francuskiej grupy farmaceutycznej Rhone-Poulenc i niemieckiej firmy Hoechst czy też powstanie koncernu Novartis po fuzji dwóch szwajcarskich producentów leków Ciba Geigy i Sandoz w 1995 r. Nowe koncerny mają odpowiednio: 3,7\% i 3,9\% udział w światowym rynku leków. Ponadto koncern Novartis zakupił w listopadzie 2002 r. 99,7\% akcji słoweńskiego producenta farmaceutyków Lek, próbuje także doprowadzić do fuzji z koncernem Roche, w którym ma już 1/3 udziałów.

Fuzje i przejęcia są ważnym celem strategicznym koncernów również ze względu na olbrzymie wydatki na prace badawcze nad nowymi lekami. Przykładem może być sojusz zawarty w październiku 2002 r. między GlaxoSmithKline a firmą Exelixis z San Francisco (w formie zakupu 3\% akcji Exelixis przez GSK), a dotyczący wspólnego opracowywania nowych leków i deklaracji na ten cel $90 \mathrm{mln}$ USD. Szacuje się, że firmy zrzeszone w Europejskiej Federacji Firm i Stowarzyszeń Farmaceutycznych (EFPIA) przeznaczają rocznie 10 mld euro na prace badawczo-rozwojowe, natomiast wydatki największego giganta światowego Pfizera na ten cel wyniosły w 2001 roku 7,1 mld USD (por. tab. 11). 
Tabela 11. Wydatki niektórych firm na prace badawczo- rozwojowe w 2001 roku

\begin{tabular}{|c|l|c|}
\hline Lp. & \multicolumn{1}{|c|}{ Kraj } & Wydatki w mld \$ \\
\hline 1. & Pfizer & 7,1 \\
\hline 2. & GlaxoSmith Kline & 3,8 \\
\hline 3 & AstraZeneca & 2,7 \\
\hline 4 & Aventis & 2,7 \\
\hline 5 & Novartis & 2,5 \\
\hline 6 & Merck\&Co & 2,5 \\
\hline \hline & EFPIA & 11,5 \\
\hline & świat & 35,0 \\
\hline
\end{tabular}

Źródło: EPFIA

W związku z tak olbrzymimi kwotami przeznaczonymi na produkcję nowych specyfików wprowadza się ochronę patentową na ich produkcję i możliwości handlu nimi. To $\mathrm{z}$ kolei rodzi problemy związane $\mathrm{z}$ piractwem leków, w krajach biednych produkuje się znacznie tańsze kopie tych leków, z pominięciem opłat licencyjnych właścicielom patentów. Najwięcej takich leków produkuje się w Brazylii i Indiach. Unia Europejska i USA walczą z piractwem na forum WTO, a z kolei kraje biedne zabiegają w Genewie o ominięcie przepisów patentowych i zezwolenia na produkcję tzw. generyków, tj. leków odtwórczych. Negocjacje prowadzone przez specjalną komisję TRIPS mają doprowadzić do ustalenia listy leków tanich, udostępnionych krajom biednym, głównie przeciwko chorobom tzw. plagowym (UE ustaliła listę 22 takich chorób), m.in. zapaleniu płuc, malarii, gruźlicy, AIDS.

\section{Literatura}

Czupiał J., 1997, Organizacja przedsiębiorstw wielonarodowych, [w:] Olszewski L., Mozrzymasa J. (red.), Struktury przemystowe w gospodarce. Aspekty ekonomiczne, spoteczno-kulturowe i polityczne, Wydawnictwo Uniwersytetu Wrocławskiego, Wrocław

Dicken P., 1992, Global shift. The internationalization of economic activity, Guilford Press: New York-London

Dicken P., 1998, Global shift. Transforming the world economy, Paul Chapman Publ. Ltd.: London

Kowalski P., 1978, Stal, „Poznaj świat”, nr 1, s. 39-40

Kukułka J., 2002, Prawa rozwoju i zmienności stosunków międzynarodowych $w$ świetle procesów globalizacji. Oblicza procesów globalizacji, Wydawnictwo UMCS, Lublin

Liberska B., 2002, Globalizacja. Mechanizmy $i$ wyzwania, Polskie Wydawnictwo Ekonomiczne, Warszawa

Moraczewska A., 2002, Korporacje transnarodowe w procesach globalizacji, [w:] Pietraś M. (red.), Oblicza procesów globalizacji, Wydawnictwo UMCS, Lublin

Zorska A., 1998, Ku globalizacji? Przemiany $w$ korporacjach transnarodowych $i w$ gospodarce światowej, Wydawnictwo Naukowe PWN, Warszawa 